\title{
Sustainable Company Value Through Price Earning Ratio, Dividend Payout Ratio And Profitability With Capital Structure As A Moderating Variable
}

\author{
Rona Tumiur Mauli Carolin Simorangkir Universitas \\ Mercu Buana University, Jakarta, Indonesia
}

\begin{abstract}
Financial performance can be assessed by looking financial reports. Financial performance that can affect company value includes the level of profitability and the level of liquidity of a company. This study discusses Sustainable Company Value through Price Earning Ratio, Dividend Payout Ratio and Profitability, with Capital Structure as a Moderation Variable.The plan for measuring the level of technological readiness used in this study is to demonstrate the concept of important functions and characteristics analytically and experimentally. (Technology readiness level 3)The purpose of this research is to see the effect of price earning ratio, dividend payout ratio, profitability on company value with capital structure as a moderating variable, which functions as an independent variable, namely price earning ratio, dividend payout ratio, and profitability proxied by return on equity. The dependent variable is the firm's value which will be calculated using Tobin's Q formula, and what functions as a moderating variable is the capital structure.Determination of the sample in this study using purposive sampling method. The property and real estate sector as a sample of this study with 90 samples, the period of this research is 3 years from 2017 to 2019, the data analysis of this study uses moderated regression analysis. The research method used in this research is quantitative method and analysis method which is planned to be used is descriptive analysis using statistical tools SPSS 21. The results of the study indicate that Price earning ratio has no effect on company value, profitability affects company value. Dividend Payout Ratio has no effect on company value. Capital structure as a moderator cannot affect the relationship between price earning ratio and company value. Capital structure as a moderator affects the relationship between profitability and company value. Capital structure does not moderate the relationship between Dividend Payout Ratio and company value.
\end{abstract}

Keywords: price earning ratio, profitability,Dividend Payout Ratio captital structure, company value, moderated DOI: $10.7176 / \mathrm{EJBM} / 13-13-08$

Publication date:July $31^{\text {st }} 2021$

\section{INTRODUCTION}

The company as a good economic entity should be able to control the financial and non-financial potential in increasing Company value in the long term. For a company, maximizing company value is very important because it also means maximizing shareholders, which is the company's main goal. A high stock price makes Company value also high, which means it will make the market believe, not only in the company's current performance, but also in the company's prospects in the future.

Several factors are thought to affect Company value, among others:

1. Price earning ratio

2. Profitability

Investors need to conduct an in-depth analysis of the movement of company value in each property company by conducting a ratio-based fundamental analysis. In practice, there are several typ es of financial ratios that can be used to measure company value. The ratios used in this study are Return On Equity (ROE), Price Earning Ratio (PER).

\section{LITERATURE REVIEW}

1. Signalling Theory

In the signal theory framework, it is stated that the company's impetus to provide information is because there is information asymmetry between company managers and outsiders, this is because company managers know more information about the company and future prospects than outsiders. Companies can increase Company value by reducing the information asymmetry. One way to reduce information asymmetry is to provide signals to outsiders, in the form of positive and reliable financial information that will reduce uncertainty about the company's future prospects so that it can lead to credibility and company success.

2. Company value

According to Harmono (2009:233), company value is the company's performance as reflected by the stock price formed by the demand and supply of the capital market which reflects the public's assessment of the company's performance. High stock prices make Company value also high and increase market confidence not only in the 
company's current performance but also on the company's prospects in the future. So that Company value is very important in measuring the performance of the company, which can affect the perception of potential investors on the level of success of the company which is often associated with stock prices.

3. Capital Structure

According to Sulindawati, et al (2016: 111), capital structure is a balance or comparison between foreign capital or own capital. Foreign capital is defined in this case as debt, both long-term and short-term debt. While the own capital can be divided into retained earnings and can also be divided into company ownership.

The capital structure shows the proportion of the use of debt to finance their investment, so that by knowing the capital structure investors can find out the balance between risk and the rate of return on their investment.

4. Price Earning Ratio (PER)

According to Tandelilin (2010: 320), companies with high growth rate opportunities usually have a high price earning ratio, and this shows that the market expects profit growth in the future. On the other hand, companies with low growth rates tend to have low price earning ratios. The lower the price earning ratio of a stock, the better or cheaper the price to invest. The price earning ratio becomes low in value because the stock price tends to decrease or because the company's net profit increases. So the smaller the value of the price earning ratio, the cheaper the shares to buy and the better the performance per share in generating profits for the company. The better the performance per share will affect many investors to buy these shares.

5. Dividend Payout Ratio

Dividend payout ratio is the ratio of the ratio of dividends that have been paid to earnings per share (Darmadji and Fakhruddin, 2012:159). Dividend Policy is a policy concerning the use of profits which are the rights of shareholders. Basically, these profits can be divided as dividends or held for reinvestment. Companies can distribute dividends in the form of cash or in the form of shares (stock dividends). Dividend Policy is still a matter of debate as there are several opinions regarding Dividends. First, the opinion that says Dividend is divided as much as possible (Dividend relevant); Second, Dividend policy is irrelevant; and the three companies pay the smallest possible dividend. If the company is able to increase dividend payments due to increased profits, then the stock price will rise. So, the increase in the share price is basically as a result of the increase in profit. Giving dividends is possible only if the company makes a profit, but it does not rule out the company still distributing dividends even though the company suffers losses

Bird in the hand theory from Bhattacharya (1979) explains that investors like high dividends because the dividends received are like birds in the hand which have less risk or reduce uncertainty compared to dividends that are not distributed. This group argues that an increase in dividends will increase stock prices which in turn have an impact on company value.

Modigliani and Miller (1958) say that dividend policy does not affect company value. In a tax-free world shareholders behave the same whether they receive cash flows as dividends, or as capital gains, if cash is held as retained earnings. While the company can choose to pay dividends from excess cash flow from operations and continue to carry out the planned investment. Because the extra funds needed can be obtained by issuing new shares without issuance fees. The value of the company does not depend on the dividend policy, because all profitable investments can be carried out without paying attention to dividend payments. A world without taxes is unrealistic because in practice the tax element will always follow every policy taken. Any dividends received by investors will be taxed. Modigliani and Miller also said that as long as dividends have a high tax rate for investors compared to capital gains, high dividends lead to high expected personal tax liabilities, so investors require high expected returns before tax. So according to them, whatever dividend policy they choose has no effect on stock prices.

6. Profitability

According to Kasmir (2009:37) Profitability is an assessment of the company's ability to seek profit. Profitability provides a measure of the level of management effectiveness of a company.

According to Sujarweni (2016:114) this ratio is used to measure the level of rewards or gains (profits) compared to sales or assets, how much is the company's ability to earn profits in relation to the sale of assets as well as profits and own capital. 
Picture 1. Conceptual Framework

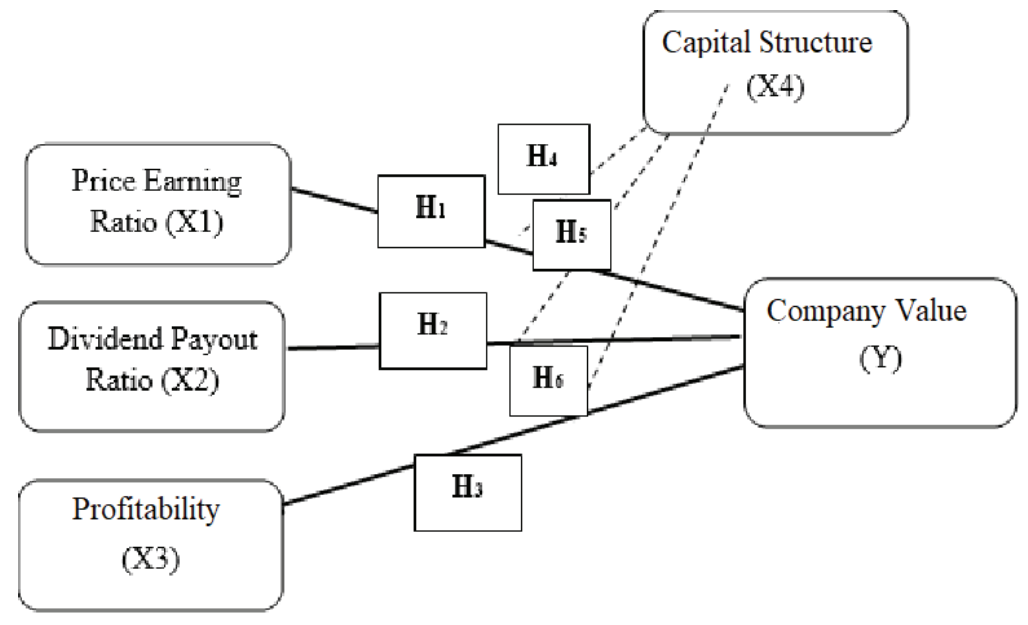

1. Effect of Price Earning Ratio on Company Value

According to Tandelilin (2010:320). Companies with high growth rate opportunities usually have a high price earning ratio, and this indicates that the market expects profit growth in the future. On the other hand, companies with low growth rates tend to have low price earning ratios. The lower the price earning ratio of a stock, the better or cheaper the price to invest. The price earning ratio becomes low in value because the stock price tends to decrease or because the company's net profit increases.

H1 : Price Earning Ratio has an effect on Company value.

2. The Effect of Dividend Payout Ratio on Company Value

Dividend Payout Ratio is a ratio to calculate how much of the profit will be distributed to shareholders and will be retained in the company for further reinvestment. Here are some reasons why dividends are still distributed even though at the same time the company has attractive investment opportunities, and the company finances the company from external sources.

1. Payment of cash dividends is common. This means that failure to pay dividends can be considered a disgrace. In addition, dividend payments can provide a signal about the company's future.

2. Dividends provide a sales point for investment banking, because some institutional investors will only buy shares of companies that pay dividends.

3.Shareholders often ask for dividends, even though the company has the opportunity to reinvest all of the funds which may be quite large.

4. There is a widespread belief that dividend payments will result in higher stock prices. Managers can use the Dividend Payout Ratio policy to ward off negative issues related to the company's performance in the future to maintain and increase the value of the company. Research conducted by Susanti (2010) found positive and insignificant results between the effect of dividend payout ratio with company value and research conducted by Isshaaq (2009), found positive and significant results between the effect of dividend payout ratio and company value. Based on Nurhayati's research (2013) it was found that dividend policy does not have a significant effect on company value.

H2: Dividend Payout Ratio has an effect on Company value.

3. The Effect of Profitability on Company Value

According to Sujarweni $(2016: 114)$ this ratio is used to measure the level of rewards or gains (profits) compared to sales or assets, how much the company's ability to earn profits in relation to the sale of assets as well as profits and own capital. According to Puspitasari and Sudiyanto (2010:15), the value of the company in the study is indicated by Tobin's Q. A high Tobin's Q value will make the market believe in the company's prospects in the future. This is also the desire of the owners of the company, because a high company value indicates the prosperity of shareholders is also high.

\section{H3 : Profitability has an effect on Company value.}

3. The effect of price earning ratio on company value with capital structure as a moderating variable

According to Nopiyanti and Darmayanti (2016), the rate of return expected by investors, profit growth and dividends has a variable value. The uncertainty of the value will also affect the value of the price earning ratio. mentions that there are two sides that can be seen on the rate of return on invested capital, namely from the investor side and from the company. If investors want a high return on invested capital, the company must be able to optimize its capital structure to be able to increase the profits of the company itself, so that returns given to investors can be higher. Viewed from the company's side, the required rate of return is the cost that must be 
incurred in order to obtain capital from shareholders. So when the company uses debt financing to increase the rate of return to investors and the company in the form of profit, the increase in the amount of debt that is relatively larger than its own capital will increase the price earning ratio. Fitrijanti and Hartono (2002) found that there is a positive relationship between price earning ratio and capital structure.

H4 : Capital structure moderates the relationship between price earning ratio and company value.

4. The effect of dividend policy on company value with capital structure as a moderating variable

Dividend payments can increase the use of debt as an external source of funding in the company's operations. With the use of debt, there will be tax savings which in turn increase the value of the company. Research from (Khoirianto, 2016) found evidence that dividend policy affects capital structure and capital structure affects Company Value. This study will prove whether capital structure as a moderating variable that can affect the relationship between dividend payout ratio and company value.

H5 : Capital structure moderates the relationship between Dividend Payout Ratio and company value.

6. Effect of Profitability on Company Value with Capital Structure as Moderating Variable

Capital structure is an important problem because the good or bad of the capital structure will have an impact on the company's financial position. The decision in choosing corporate funding is very important, besides being able to affect the company's capital structure, choosing the right funding will also affect the company's profitability. (Kusumajaya, 2011). Research conducted by Munthe (2018) and Wijaya and Pancawati (2019) states that capital structure is able to moderate the effect of profitability on Company Value. In contrast, the results of research by Dharmawan, Ciptaningrum and Aryoko (2020) state that capital structure is not able to moderate the relationship between profitability and Company Value. in manufacturing companies in the consumer goods industry sector.

H6 : Capital structure moderates the relationship between Profitability and company value.

\section{RESEARCH METHODS}

In this research, the analytical method used is multiple linear regression analysis method. This method aims to examine the effect of one or more independent variables on one dependent variable (Ghozali, 2013:7).

This study uses a causal relationship research design. Causal research is research that aims to determine the effect of one or several variables (independent variable) on other variables (dependent variable).

\subsection{Definition and Operational Variable}

1. Variable Definition

In this study, the dependent variable is Company Value (Y). The independent variables consist of Price Earning Ratio (PER) (X1), Dividend Payout Ratio (X2) Profitability (X3), and there is a moderating variable, namely capital structure (X4).

a. Company Value (Y)

According to (Puspitasari \& Sudiyanto, 2010:15), the value of the company in the study is indicated by Tobin's Q. A high Tobin's Q value will make the market believe in the company's future prospects. This is also the desire of the owners of the company, because a high company value indicates the prosperity of shareholders is also high. Tobin's Q is the ratio between market value and debt divided by total assets. Market value is the number of ordinary shares of the company outstanding multiplied by the closing price of the shares.

The following is the formula for the value of the company with the Tobin's Q variable:

$$
\begin{array}{ll}
\text { Tobin's } Q=\frac{M E+D e b t}{T A} \\
\text { MVE } & \text { : Market Value } \\
\text { Debt } & \text { : Total Debt } \\
\text { TA } & \text { : Total Activa }
\end{array}
$$

b. Price Earning Ratio (PER) (X1)

According to (Tandelilin, 2010:320), the formula for calculating the PER of a share to divide the company's share price against earnings per share. Mathematically, the formula for calculating PER is as follows: Price per share

$$
\mathrm{PER}=
$$

Earning per share

c. Dividend Payout Ratio (DPR) (X2)

Variabel dividend payout ratio digunakan Dividend Payments diberi simbol DPO didefinisi sebagai dividend payout ratio (Nurhayati, 2008).

Dividend Payout Ratio= Dividend pershare

Earning per share 


\section{d. Profitability (X3)}

According to (Sujarweni, 2016:114) this ratio is used to measure the level of rewards or gains (profits) compared to sales or assets how much the company's ability to earn profits in relation to the sale of assets as well as profits and own capital, this is shown by the profits generated from sales and investment income as for the type of profitability measurement: Rate or return for the owners (Rate of Return on net worth)

$\mathrm{ROE}=$ Net profit after tax

e. Capital Structure (X3)

$$
\text { Equity }
$$

According to (Horne \& John, 2012:170) the variables included in the structure because it can reflect the comparison between debt, equity and assets which are components of the capital structure, namely: Debt to Asset Ratio Debt to Asset Ratio (DAR) is a ratio used to show how much a company uses debt to finance its total assets or assets. This ratio can be formulated as follows:

$$
\begin{aligned}
\text { Debt to Asset Ratio }= & \text { Total Debt } \\
- & \text { Total Asset }
\end{aligned}
$$

f. Debt to Equity Ratio Debt to Equity Ratio (DER) is the ratio used to show how much the company uses funding obtained through debt when compared to funding obtained through its own capital. This ratio can be formulated as follows:

$$
\text { Debt to Equity Ratio }=\quad \text { Total Debt }
$$

\subsection{OPERATION VARIABLES}

\begin{tabular}{l} 
Total Debt \\
\hline Equity
\end{tabular}

Operationalization variables is needed to determine the types of indicators and the scale of the variables involved in the study, so that hypothesis testing with statistical tools can be carried out correctly according to the research title Effect of Price Earning Ratio (PER), Profitability on Company value with Capital Structure as a Variable Moderation.

\section{Moderating Variables}

According to (Solimun, 2017:83), the moderating variable plays a role in accompanying the explanatory and serves to influence the relationship of the explanatory variable to the response variable. This function is often interpreted as a moderating variable as a variable that plays a role in strengthening or weakening the relationship

\begin{tabular}{|c|c|c|c|}
\hline No & Variable & Indicator & Scale \\
\hline 1 & Price Earning Ratio & 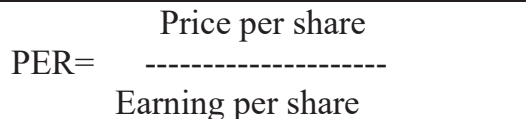 & Ratio \\
\hline 2 & Dividend Payout Ratio & 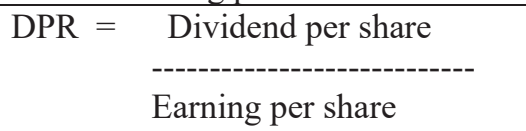 & Ratio \\
\hline 3 & Profitability & $\begin{array}{cl}\mathrm{ROE}= & \text { Net profit after tax } \\
& -\mathrm{-} \text { Equity }\end{array}$ & Ratio \\
\hline 3 & Capital Structure & 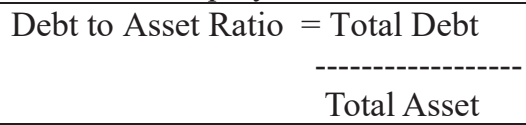 & Ratio \\
\hline 4 & Company Value & Tobin's Q $=\frac{M V E+D e b t}{T A}$ & Ratio \\
\hline
\end{tabular}
between the explanatory/predictor variable and the response variable.

To clarify and emphasize the variables studied, these variables will be operationalized as follows:

Table 1. Operational Variable Measurement Method

\section{Population and Research Sample}

The population of this study is property companies listed on the Indonesia Stock Exchange (IDX) during 2016 2019. In this study, the sample was taken using the purposive sampling method, which is a research sample that is limited to certain types that can provide the desired information, with the reason is that company data is the only one that has or meets several criteria determined by the researcher, the number of samples in this study is 72 samples. 


\section{RESULTS AND DISCUSSION}

\section{A. RESULTS}

Table 2 Descriptive Statistical Test Results

\begin{tabular}{|l|r|r|r|r|r|}
\hline & & & & & $\begin{array}{c}\text { Std. } \\
\text { Deviation }\end{array}$ \\
\hline PER & $\mathrm{N}$ & Minimum & Maximum & \multicolumn{1}{c|}{ Mean } & 78.2065499 \\
\hline & 72 & 0.4764 & 483.3333 & 33.001757 & 0.0598487 \\
\hline DIVIDEND PAYOUT RATIO & 72 & 0.0010 & 0.3221 & 0.092828 & 0.052 \\
\hline PER*CAPITAL STRUCTURE & 72 & 0.0000 & 0.3435 & 0.052983 & 0.0827530 \\
\hline PROFITABILITY*CAPITAL STRUCTURE & 72 & 0.1172 & 135.4033 & 18.081367 & 30.4569320 \\
\hline DPR*CAPITAL STRUCTURE & 72 & 0.0002 & 0.5386 & 0.071987 & 0.0833291 \\
\hline COMPANY VALUE & 72 & 0.0667 & 2.7827 & 0.942772 & 0.5086337 \\
\hline Valid N (listwise) & 72 & & & & \\
\hline
\end{tabular}

Source: SPSS output, data processed 2021

From table 2 it can be seen that:

$1 . \mathrm{N}=72$, indicating that the number of data in this study is 72 samples.

2. Company Value

Company value by measurement using the Tobin's Q calculation method by taking into account Market Value Equity plus Debt divided by total assets. The results of the descriptive statistical test show that the company value has an average of 0.942772 with a standard deviation of 0.5086337 , meaning that the company has a composition between market value equity, debt with total assets having a presentation of $94 \%$, and the company value having a maximum value of 2.7827 which has the value is PT. Sitara Propertindo Tbk in 2018 which has the best composition of company value, while the one with the smallest composition of company value with a minimum value of 0.06667 which has this value is PT. Bumi Citra Permai Tbk in 2018.

3.Price Earning Ratio (PER)

Price earning ratio has a measurement with a comparison between Earning Per Share divided by the price per share. The results of the descriptive statistical test have an average value of 33.001757 with a standard deviation of 78.2065499, meaning that the company has a large sales profit, from the results of the SPSS test of the price earning ratio variable having a maximum value of 483.333 this value is owned by the company PT. Sitara Propertindo Tbk and a minimum score of 0.47.Profitabilitas

4. Return On Equity (ROE), has a comparison between net income divided by

total equity. The results of the descriptive statistical test have an average value of 0.092828 with a standard deviation of 0.0598 , meaning that the company has a pretty good profit ratio of around $5.98 \%$, from the results of this test the maximum value owned by profitability is 0.3221 and the minimum value is 0.0010 . .

Dividend Payout Ratio

DPR (Dividend Payout Ratio), has a comparison between dividends divided by net income. The results of the descriptive statistical test have an average value of 0.052983 , with a standard deviation of 0.0827530 , meaning that the company has a fairly small dividend ratio of $5.29 \%$, from this result the maximum value of the dividend policy is 0.3435 and the minimum value is 0.0000 .

\section{A. CLASSICAL ASSUMPTION TEST}

1. Normality test

Table 3. One-Sample Kolmogorov-Smirnov Test

\begin{tabular}{|c|c|c|}
\hline & & Unstandardized Residual \\
\hline \multicolumn{2}{|l|}{$\mathrm{N}$} & 72 \\
\hline \multirow[t]{2}{*}{ Normal Parameters ${ }^{\mathrm{a}, \mathrm{b}}$} & Mean & 0.0000000 \\
\hline & Std. Deviation & 0.47613181 \\
\hline \multirow{3}{*}{$\begin{array}{ll}\text { Most } & \text { Extreme } \\
\text { Differences } & \end{array}$} & Absolute & 0.084 \\
\hline & Positive & 0.074 \\
\hline & Negative & -0.084 \\
\hline \multicolumn{2}{|l|}{ Test Statistic } & 0.084 \\
\hline \multicolumn{2}{|l|}{ Asymp. Sig. (2-tailed) } & $.200^{\mathrm{c}, \mathrm{d}}$ \\
\hline \multicolumn{3}{|c|}{ a. Test distribution is Normal. } \\
\hline \multicolumn{3}{|l|}{ b. Calculated from data. } \\
\hline \multicolumn{3}{|c|}{ c. Lilliefors Significance Correction. } \\
\hline
\end{tabular}

Source: SPSS output, data processed 2021

The data in table 3 above shows that the residual data between the independent variable and the dependent variable has a Kolmogorov-Smirnov Z statistical value of 0.084, and has an Asymp.Sig of 0.200>0.05, then the 
data in this study means that it is normally distributed, so the data can be used for further research.

Table 4 Multikolinieritas test

$$
\text { a. Multikolonieritas test }
$$

\begin{tabular}{|c|c|c|c|}
\hline \multirow{2}{*}{\multicolumn{2}{|c|}{ Model }} & \multicolumn{2}{|c|}{ Collinearity Statistics } \\
\hline & & Tolerance & VIF \\
\hline \multirow[t]{6}{*}{1} & (Constant) & & \\
\hline & PER & 0.373 & 2.679 \\
\hline & PROFITABILITY & 0.486 & 2.059 \\
\hline & DIVIDEND PAYOUT RATIO & 0.902 & 1.109 \\
\hline & PER*CAPITAL STRUCTURE & 0.312 & 3.210 \\
\hline & DPR*CAPITAL STRUCTURE & 0.426 & 2.349 \\
\hline
\end{tabular}

Source: SPSS output, data processed 2021

Multicollinearity can also be seen from the tolerance value and its opposite, variance inflation factor (VIF). A low value equals a high VIF value (because VIF $=1 /$ Tolerance). The cutoff value commonly used for multicollinearity is the tolerance value $>0.10$ or the same as the VIF value $<10$ (Ghozali, 2016: 105).Uji

Table 5. Autokorelation test

$$
\text { b. Autokorelation Test }
$$

\begin{tabular}{|c|c|c|c|c|c|c|}
\hline \multicolumn{7}{|c|}{ Model Summary $^{\mathbf{b}}$} \\
\hline Model & $\mathrm{R}$ & R Square & $\begin{array}{l}\text { Adjusted } \\
\text { Square }\end{array}$ & $\mathrm{R}$ & $\begin{array}{l}\text { Std. Error of the } \\
\text { Estimate }\end{array}$ & Durbin- Watson \\
\hline 1 & $.401 \mathrm{a}$ & 0.161 & 0.148 & & 0.44226328 & 1.836 \\
\hline \multicolumn{7}{|c|}{ a. Predictors: (Constant), COMPANY VALUE } \\
\hline \multicolumn{7}{|c|}{ b. Dependent Variable: PER, PROFITABILITAS,DIVIDEND PAYOUT RATIO,PER*CAPITAL } \\
\hline
\end{tabular}

Source: SPSS output, data processed 2021

The autocorrelation test aims to test whether in a regression model there is a correlation between confounding errors in the current period $(\mathrm{t})$ with errors in the previous period (t-1) (Ghozali, 2016:110). A good regression model is a regression that is free from autocorrelation. This test can be carried out by means of the Durbin-Watson (DW test). With a confidence level of $=5 \%$. And it can be seen that if the Durbin test exceeds 0.05 for the level of confidence in this study is 1.836 , it can be concluded that in this case there is no autocorrelation symptom.

c. Heteroscedasticity Test

The heteroscedasticity test shows that the variance of the residuals is not the same from one observation to another. These unequal residual symptoms are called heteroscedasticity symptoms. If the variance of the residuals remains, it is called homoscedasticity and if it is different it is called heteroscedasticity (Imam Ghozali, 2016). One of the tests to test this heteroscedasticity is the Park Test, the Park Test proposes to regress the absolute value of the residual on the independent variable. The basis for decision making with the park test is to regress the absolute value of the residual on the independent variable and if the probability level of significance is above the $5 \%$ confidence level $(\alpha=0.05)$, it can be concluded that the regression model does not contain heteroscedasticity. 


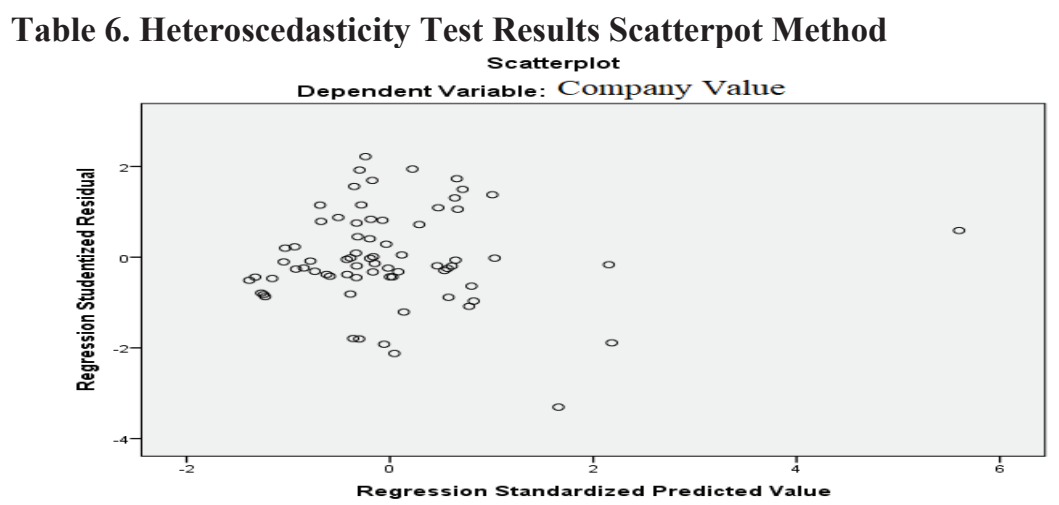

Source: SPSS output, data processed 2021

It can be seen in the picture above that, the data points spread above and below or around the number 0 , the points do not collect only above or below, and the spread of data points should not form a wavy pattern that widens then narrows and widen return, and the distribution of data points is not patterned, it can be concluded that the data in this study does not have symptoms of heteroscedasticity.

\section{B. HYPOTHESIS TEST}

Moderated Regression Analysis (MRA)

Moderated Regression Analysis (MRA) is a special approach to linear multiple regression in which the regression equation contains elements of intersection. This MRA analysis is not only to see whether there is an effect of the independent variable on the dependent variable as well as to see whether the moderating variable in the model can increase the effect of the moderating variable, it can be seen how much influence it has on the relationship between Price Earning Ratio (PER), and Profitability, e as the independent variable and company value as the dependent variable, whether it is strengthening or weakening, and has the following equation:

$$
\mathrm{Y}=\alpha+\beta 1 \mathrm{X} 1+\beta 1 \mathrm{X} 2+\beta 1 \mathrm{X} 3+\varepsilon
$$

$\mathrm{Y}=\alpha+\beta 1 \mathrm{X}+\beta 1 \mathrm{X} 2+\beta 1 \mathrm{x} 3+\beta 1 \mathrm{X} 1 * \mathrm{M}+\beta 1 \mathrm{X} 2 * \mathrm{M}+$

$$
\beta 1 \mathrm{X} 3 * \mathrm{M}+\varepsilon \ldots \ldots(2)
$$

\begin{tabular}{|c|c|c|c|c|}
\hline \multicolumn{5}{|c|}{ Model Summary ${ }^{b}$} \\
\hline Model & $\mathrm{R}$ & R Square & Adjusted R Square & Std. Error of the Estimate \\
\hline 1 & $.352 \mathrm{a}$ & 0.124 & 0.085 & 0.4865214 \\
\hline
\end{tabular}

Table 7. $\mathbf{R}$ - Square test results before moderation

Source: SPSS output, data processed 2021

Table 7 has an R Square value of 0.124 , meaning that 12.4 percent of the firm's value can be explained by the variable price earning ratio, profitability, dividend policy, while 87.6 percent is explained by variables not included in this study.

\begin{tabular}{|c|c|c|c|c|c|c|}
\hline \multicolumn{7}{|c|}{ Model Summary $^{\mathbf{b}}$} \\
\hline Model & $\mathrm{R}$ & R Square & $\begin{array}{l}\text { Adjusted } \\
\text { Square }\end{array}$ & & $\begin{array}{l}\text { Std. Error of the } \\
\text { Estimate }\end{array}$ & Durbin- Watson \\
\hline 1 & $.401^{\mathrm{a}}$ & 0.161 & 0.148 & & 0.44226328 & 1.836 \\
\hline \multicolumn{7}{|c|}{$\begin{array}{lccc}\text { Predictors: } & \text { (Constant), } & \text { PER, } & \text { PROFITABILITY,DPR, } \\
\text { RE ,PROFITABILITY*CAPITAL STRUCTURE ,DPR*CAPITAL STRUCTURE }\end{array}$} \\
\hline
\end{tabular}

Table 8. $\mathbf{R}$ - Square test results after moderation

In table 8 it has a value of 0.161 where in the research in table 8 there is moderation, which means that 16.1 percent of company value can be explained by the variable price earning ratio, profitability, dividend policy, interaction of price earning ratio with capital structure, interaction of profitability with capital structure, interaction of dividend policy on capital structure.

It can be concluded that prior to the moderation of the capital structure, this study had an R-Square of 0.124 , and after moderating the R-Square capital structure increased by 0.161 , which means that the capital structure 
can moderate the price earning ratio, dividend policy profitability or one of them.

Table 9. Test Results Before Moderated Regression Analysis (Test Variable X against Y)

\begin{tabular}{|c|c|c|c|c|c|c|}
\hline \multicolumn{7}{|c|}{ Coefficients $^{\mathrm{a}}$} \\
\hline & & \multicolumn{2}{|c|}{ Unstandardized Coefficients } & \multirow{2}{*}{$\begin{array}{c}\text { Standardized } \\
\text { Coefficients } \\
\text { Beta } \\
\end{array}$} & \multirow[b]{2}{*}{$\mathrm{t}$} & \multirow[b]{2}{*}{ Sig. } \\
\hline \multicolumn{2}{|c|}{ Model } & B & Std. Error & & & \\
\hline \multirow[t]{4}{*}{1} & (Constant) & 0.596 & 0.143 & & 4.176 & 0.000 \\
\hline & PER & 0.001 & 0.001 & 0.186 & 1.493 & 0.140 \\
\hline & PROFITABILITY & 3.232 & 1.080 & 0.380 & 2.992 & 0.004 \\
\hline & DPR & 0.126 & 0.732 & 0.021 & 0.172 & 0.864 \\
\hline
\end{tabular}

a. Dependent Variable: COMPANY VALUE

Source: SPSS output, data processed 2021

Table 9 above shows that the unstandardized coefficient has the beta equation: $\mathrm{Y}=0.596+0.001 \mathrm{PER}+3.232 \mathrm{ROE}+0.126 \mathrm{DPR}+\varepsilon$

In this equation there is no moderation of the capital structure, namely the result of the multiplication between each variable on the capital structure. In this MRA equation, it can be seen that the B value of the unstandardized coefficients, the B value of constant is 0.596, the B PER value is 0.001 , and the B value for profitability is 3.232 , and the $\mathrm{B}$ value for dividend policy is 0.126 .

Tabel 10. Test Results After Moderated Regression Analys (Test Variable X moderates M against Y)

\begin{tabular}{|c|c|c|c|c|c|c|}
\hline \multicolumn{7}{|c|}{ Coefficients $^{\mathrm{a}}$} \\
\hline \multirow{2}{*}{\multicolumn{2}{|c|}{ Model }} & \multicolumn{2}{|c|}{ Unstandardized Coefficients } & \multirow{2}{*}{$\begin{array}{c}\begin{array}{c}\text { Standardized } \\
\text { Coefficients }\end{array} \\
\text { Beta }\end{array}$} & \multirow[b]{2}{*}{$\mathrm{t}$} & \multirow[b]{2}{*}{ Sig. } \\
\hline & & $\mathrm{B}$ & Std. Error & & & \\
\hline 1 & (Constant) & 0.477 & 0.130 & & 3.669 & 0.000 \\
\hline & PER & -0.001 & 0.001 & -0.198 & -1.216 & 0.228 \\
\hline & PROFITABILITY & 2.782 & 1.212 & 0.327 & 2.296 & 0.025 \\
\hline & DPR & 0.390 & 0.643 & 0.064 & 0.607 & 0.546 \\
\hline & PER*CAPITAL STRUCTURE & 0.009 & 0.003 & 0.561 & 3.149 & 0.082 \\
\hline & $\begin{array}{l}\text { PROFITABILITY*CAPITAL } \\
\text { STRUCTURE }\end{array}$ & 3.185 & 1.287 & 0.417 & -2.332 & 0.031 \\
\hline & DPR*CAPITAL STRUCTURE & 0.836 & 0.930 & 0.137 & 0.899 & 0.372 \\
\hline
\end{tabular}

Dependent Variable: COMPANY VALUE

Source: SPSS output, data processed 2021

The table 10 above shows that the unstandardized coefficient has the beta equation:

$\mathrm{Y}=0.477-0.001 \mathrm{PER}+2.782 \mathrm{ROE}+0.390 \mathrm{DPR}-$

$0.001 \mathrm{PER} * 0.009 \mathrm{DER}+2.782 \mathrm{ROE} * 3.185 \mathrm{DER}+0.390 \mathrm{DPR} * 0.836 \mathrm{DER}+\varepsilon$

In the equation above, there is moderation between each variable on the moderating variable (capital structure) which will affect the dependent variable.

\section{SIMULTANEOUS SIGNIFICANCE TEST (F STATISTICS TEST)}

For the purposes of decision making, the significance level of $0.05(5 \%)$ is used. The conditions for accepting or rejecting the hypothesis are as follows:

a. If the probability value $>0.05$ then the independent variable simultaneously does not significantly affect the dependent variable.

b. If the probability value is $<0.05$, the independent variable simultaneously significantly affects the dependent variable. 
Tabel 11 F . Statistical Test Results

\begin{tabular}{|c|c|c|c|c|c|c|}
\hline \multicolumn{7}{|c|}{ ANOVA $^{\mathrm{a}}$} \\
\hline \multicolumn{2}{|c|}{ Model } & Sum of Squares & df & Mean Square & $\mathrm{F}$ & Sig. \\
\hline \multirow[t]{3}{*}{1} & Regression & 6.397 & 5 & 1.279 & 7.054 & $.000^{\mathrm{b}}$ \\
\hline & Residual & 11.971 & 66 & 0.181 & & \\
\hline & Total & 18.368 & 71 & & & \\
\hline \multicolumn{7}{|c|}{ a. Dependent Variable: COMPANY VALUE } \\
\hline \multicolumn{7}{|c|}{$\begin{array}{l}\text { b. Predictors: (Constant), DPR*CAPITAL STRUCTURE , DPR, PER, PROFITABILITY, } \\
\text { PER*CAPITAL STRUCTURE }\end{array}$} \\
\hline
\end{tabular}

Source: SPSS output, data processed 2021

Based on table 11 shows that the $F$ test value is 6397 and significant at 0.000 . The significant value of 0.000 when compared to the value of $0.050(5 \%)$ is smaller, this indicates that the regression model used in this study is feasible. So it can be concluded that this regression model is fit to explain the effect of price earning ratio (PER), Profitability, Dividend Policy on company value with capital structure as a moderating variable.

\section{INDIVIDUAL PARAMETER STATISTICAL TEST (T STATISTICAL TEST)}

This test basically shows how far the influence of one independent variable individually in explaining the variation of the dependent variable. The test is carried out using a significance level of $0.05(=5 \%)$. If the significance value of $\mathrm{t}>0.05$ or $\mathrm{t}$ count $<\mathrm{t}$ table then Ho is accepted and Ha is rejected (regression coefficient is not significant). This shows that partially the independent variable has no significant effect on the dependent variable.

If the significance value of $t<0.05$ or $t$ count $>t$ table then Ho is rejected and Ha (regression coefficient is significant). This shows that partially the independent variable has a significant effect on the dependent variable.

Table 12. T Test Results (Test Variable X Against Y)

\begin{tabular}{|c|c|c|c|c|c|c|}
\hline \multicolumn{7}{|c|}{ Coefficients $^{\mathbf{a}}$} \\
\hline \multirow{2}{*}{\multicolumn{2}{|c|}{ Model }} & \multicolumn{2}{|c|}{ Unstandardized Coefficients } & \multirow{2}{*}{$\begin{array}{c}\text { Standardized } \\
\text { Coefficients } \\
\text { Beta } \\
\end{array}$} & \multirow{2}{*}{$\mathrm{T}$} & \multirow{3}{*}{$\frac{\text { Sig. }}{0.000}$} \\
\hline & & B & Std. Error & & & \\
\hline 1 & (Constant) & 0.477 & 0.130 & & 3.669 & \\
\hline & PER & -0.001 & 0.001 & -0.198 & -1.216 & 0.228 \\
\hline & PROFITABILITY & 2.782 & 1.212 & 0.327 & 2.296 & 0.025 \\
\hline & DPR & 0.390 & 0.643 & 0.064 & 0.607 & 0.546 \\
\hline & PER*CAPITAL STRUCTURE & 0.009 & 0.003 & 0.561 & 3.149 & 0.082 \\
\hline & $\begin{array}{l}\text { PROFITABILITY*CAPITAL } \\
\text { STRUCTURE }\end{array}$ & 3.185 & 1.287 & 0.417 & 2.332 & 0.031 \\
\hline & DPR*CAPITAL STRUCTURE & 0.836 & 0.930 & 0.137 & 0.899 & 0.372 \\
\hline
\end{tabular}

Dependent Variable: COMPANY VALUE

Source: SPSS output, data processed 2021

a. Based on table 12, the results of the $t$ test and the significant results of testing each independent variable on the dependent can be concluded as follows:

b. The calculated t value for the Price Earning Ratio (X1) variable as measured by the profit per share with the $\mathrm{t}$ value is -1.216 with a significant level of 0.228 . Because $\mathrm{t}$ count $<\mathrm{t}$ table and the significant level is greater than 0.05 , then $\mathrm{H} 1$ is rejected and $\mathrm{H} 0$ is rejected. Thus, it can be concluded that the price earning ratio has no effect on company value.

c. The calculated t value for the profitability variable (X2) for the comparison between the company's net income and total equity with a $t$ value of 2.296 and a significant level of 0.025 . The value of $t$ count $>t$ table and the significant level is less than 0.05 then $\mathrm{H} 2$ is accepted and H0 is accepted. Thus it can be concluded that profitability has a significant positive and significant effect on company value.

d. The $t$ value of the dividend policy variable (X3) for the comparison of dividends divided by net income with a $t$ value of 0.607 and a significant level of 0.546 . Because $t$ count $<t$ table and the significant level is greater than $0.05, \mathrm{H} 3$ is rejected and $\mathrm{H} 0$ is rejected. Thus it can be concluded that dividend policy has no effect on company value.

e. The interaction between price earning ratio and capital structure has a $t$ value of 3.149 with a sig value of 0.082. The $t$ count $>t$ table and a significant level less than 0.05 then $\mathrm{H} 4$ is accepted and $\mathrm{H} 0$ is rejected. Thus it can be concluded that the capital structure as a moderator affects the relationship between price earning ratio and company value. 
f. The interaction between profitability and capital structure has a $t$ value of 2.233 with a sig value of 0.031 . T count $>\mathrm{t}$ table and a significant level less than 0.05 then H5 is accepted and H0 is accepted. Thus it can be concluded that the capital structure as a moderator affects the relationship between profitability and company value.

g. The interaction between dividend policy and capital structure has a t value of 0.899 with a sig value of 0.372 , a $t$ count $<t$ table and a significant level greater than 0.05 , so H6 is rejected and H0 is rejected. Thus, it can be concluded that the capital structure as a moderator does not affect the relationship between dividend policy and company value.

\section{MULTIPLE LINEAR REGRESSION TEST}

Used to test whether or not there is an effect of price earning ratio, and profitability on company value as measured by Tobin's Q. Based on the regression output above, the multiple linear regression analysis model used in this study can be formulated as follows:

Before moderation

$\mathrm{Y}=\mathrm{a}+\mathrm{b} 1 \mathrm{X} 1+\mathrm{b} 2 \mathrm{X} 2+\mathrm{b} 3 \mathrm{X} 3+\varepsilon$

$\mathrm{Y}=0.596+0.001 \mathrm{PER}+3.232 \mathrm{ROE}+0.126 \mathrm{DPR}+\varepsilon$

The regression equation can be explained as follows:

a. If the variables of price earning ratio, profitability, and dividend policy are considered constant, the value of the company value (Y) has increased by $0.596(59.6 \%)$.

b. If the price earning ratio (X1) increases by $1 \%$ (assuming that the coefficients of other variables remain or do not change), it will decrease by $0.001(1 \%)$.

c. If profitability (X2) increases by $1 \%$ (assuming that the coefficients of other variables remain or do not change) it will increase by $3.232(32.32 \%)$.

d. If the dividend policy (X3) increases by $1 \%$ (assuming that the coefficients of other variables remain or do not change), it will decrease by $0.126(12.6 \%)$.

After moderation

$\mathrm{Y}=\mathrm{a}+\mathrm{b} 1 \mathrm{X} 1+\mathrm{b} 2 \mathrm{X} 2+\mathrm{b} 3 \mathrm{X} 3+\mathrm{b} 4 \mathrm{M} 1+\mathrm{b} 5 \mathrm{M} 2+\mathrm{b} 6 \mathrm{M} 3+\varepsilon$

$\mathrm{Y}=0.437-0.001 \mathrm{PER}+2.782 \mathrm{ROE}+0.390 \mathrm{DPR}+0.009 \mathrm{PER} * \mathrm{DER}+3.185 \mathrm{ROE} * \mathrm{DER}+0.8$

$36 \mathrm{DPR} * \mathrm{DER}+\varepsilon$

a. If the variable price earning ratio and profitability are considered constant, the value of the company value (Y) has increased by $0.437(43.7 \%)$.

b. If the price earning ratio (X1) increases by $1 \%$ (assuming that the coefficients of other variables remain or do not change), it will decrease by $-0.001(1 \%)$.

c. If the profitability (X2) increases by $1 \%$ (assuming that the coefficients of other variables remain or do not change), it will increase by $2,782(27.82 \%)$.

d. If the dividend policy (X3) If the dividend policy (X3) there is an increase of $1 \%$ (assuming that the coefficients of other variables remain or do not change) it will decrease by $0.390(39 \%)$.

e. If the price earning ratio*capital structure (M1) increases by $1 \%$ (assuming that the coefficients of other variables remain or do not change), it will decrease by $0.0009(0.09 \%)$.

f. If profitability*capital structure (M2) increases by $1 \%$ (assuming that the coefficients of other variables remain or do not change) it will increase by 3,185

$(31.85 \%)$.

g. If the dividend policy*capital structure (M3) increases by $1 \%$ (assuming that the coefficients of other variables remain or do not change) it will decrease by $0.836(86.6 \%)$.

\section{B. DISCUSSION}

\section{Effect of price earning ratio on company value}

Based on table 12, the $t$ value is calculated for the Price Earning Ratio (X1) variable as measured by profits per share with a $t$ value of -1.216 with a significant level of 0.228 . Because $t$ count $<t$ table and the significant level is greater than 0.05 , then $\mathrm{H} 1$ is rejected and $\mathrm{H} 0$ is rejected. Thus it can be concluded that the price earning ratio has no effect on the value of the company, the meaning of not having an effect is that the price earning ratio is that each investor sees from a different point of view, such as investors seeing the company's stock price is cheap or worth buying because it has the potential to rise in the future.

For companies, the impact of the price earning ratio reflects a good indicator to determine stock returns in the future, where the higher the price per share of a company also indicates a good company value, so that the company's shares can be categorized as blue chip companies. the company's ability to generate profits in future earnings of a company. Investors who like to take risks (risk takers) have a tendency to speculate so that they prefer a higher price earning ratio. The higher the price earning ratio indicates that the stock price is increasing and the increase in the stock price has the potential to bring profits on the difference in stock prices that occur. 
This study is in line with the journal (Bhekti, 2014).

\section{The effect of profitability on company value}

Based on table 12, the $t$ value is 2.296 and the significant level is 0.025 . The value of $t$ count $>t$ table and the significant level is less than 0.05 then $\mathrm{H} 2$ is accepted and $\mathrm{H} 0$ is accepted. Thus, it can be concluded that profitability has a significant positive and significant effect on company value. the purpose of the positive effect is profitability, the value of profitability increases and the value of a company's company increases, the company is the company's ability to generate net income from activities carried out in the accounting period. High profitability will provide an indication of good company prospects so that it can trigger investors to participate in increasing demand for shares. Furthermore, the increasing demand for shares will cause the value of the company to increase.

Profitability can be calculated by Return On Equity(ROE). ROE reflects the return on investment for shareholders. High profitability reflects the company's ability to generate high profits for shareholders. With a high profitability ratio owned by a company will attract investors to invest in the company. High ROE will increase stock prices, and will attract investors to invest their capital in the company. So, there will be a positive relationship between profitability and stock prices where the high stock price will affect the value of the company.

The higher the company's profitability will also increase the company's earnings per share. An increase in the company's earnings per share will make investors interested in investing by buying company shares. With many investors who buy company shares, it will increase the company's share price so that it will increase the value of the company., in this study it can support the journal of (Nopiyanti \& Darmayanti, 2017)

\section{The effect of dividend policy on company value}

Based on table 12, the $t$ value is 0.607 and the significant level is 0.546 . The value of $t$ count $>t$ table and the significant level is less than 0.05 , so $\mathrm{H} 2$ is rejected and $\mathrm{H} 0$ is rejected. Can be concluded that dividend policy has no effect on company value, because there are assumptions which say that there is no relationship between company value and company value.

In aggregate, investors only see the total return from investment decisions. Investors do not see whether it comes from capital gains or dividend income, so the resulting profit will be distributed as dividends or retained earnings, so that there is no effect on company value, in theory this is in line with research results from (Sihotang \& Saragih, 2017)

\section{Capital structure as a moderator affects the relationship between price earning ratio and company} value

Based on table 12, the t-value has a t-value of 3.149 with a sig value of 0.082 . The t-count value $>$ t-table and the significant level is less than 0.05 , so $\mathrm{H} 4$ is accepted and $\mathrm{H} 0$ is rejected. Thus, the capital structure as a moderator does not affect the relationship between price earning ratio and company value.

From the results of this study it can be concluded that the company has not been able to reflect the company's capital or debt for expansion purposes. What is meant by expansion is using the company's capital or debt to improve company performance, so that the company can increase the price earning ratio, thus investors do not believe in buying shares from property companies.

Investors should be able to use the company's debt for expansion purposes, so that it can attract investors to buy shares in property companies and can increase or maintain the existence of the company. And can experience improvement every year, so this research is in line with the journal (Bhekti, 2014).

5. Capital structure as a moderator affects the relationship between profitability and company value Based on table 12, the $t$ value is 2.233 with a sig value of 0.031 . The $t$ count value $>t$ table and the significant level is less than 0.05, so H5 is accepted and H0 is accepted. Thus it can be concluded that the capital structure moderates the interaction between profitability and company value. the capital structure also strengthens the relationship between profitability and company value which can be seen, in this study property companies have high profitability which can be seen from the high profit compared to the company's equity value, so the company can pay obligations from the company's profits guarantees to pay their obligations, companies that have high profitability, the company's performance is getting better, so investors can invest, because looking at the high profitability ratio of the company so that investors get bigger dividends, and can achieve the desired profit, in this study supports and in line with the journal (Nopiyanti \& Darmayanti, 2017).

6. Capital structure as a moderator affects the relationship between Dividend Payout Ratio and company value

Based on table 12, the $\mathrm{t}$ value is 0.899 with a sig value of 0.372 , the $\mathrm{t}$ count value is $<\mathrm{t}$ table and the significant level is greater than 0.05 , then $\mathrm{H} 6$ is rejected and $\mathrm{H} 0$ is rejected. With the results of this study, it can be concluded that the capital structure does not moderate the relationship between dividend policy and company value, because if the company has a high use of capital structure, the company tends to pay dividends a little, because the company will make retained earnings (part or all of the profits are distributed in in the form of dividends), so retained earnings are used as reserves to cover debt to pay the company's obligations. in this study 
is in line with research (Efendi Irfan, 2019)

\section{CONCLUSIONS}

Based on the results of data analysis and discussion of the analysis of the effect of price earning ratio, and profitability on company value with capital structure as a moderating variable, it can be concluded:

1. Price earning ratio has no effect on company value. This is in accordance with the indication that the profits obtained from the sale of each share tend to have a high enough opportunity to increase the value of the company so that it can attract investors to invest in property companies.

2. Profitability affects the value of the company, because the results of the company's performance can be assessed on the value of the profitability of a company, where there is a measurement of the ratio for profitability, in this study assessed by ROE (Return On Equity), namely the ratio between net income and total equity, the higher the ratio, the value of the company will be higher

3. The dividend policy as proxied by the dividend payout ratio has no effect on company value

4. Capital structure as a moderator cannot affect the relationship between price earning ratio and company value.

5. Capital structure as a moderator affects the relationship between profitability and company value.

6. Capital structure does not moderate the relationship between dividend policy and company value.

\section{SUGGESTIONS}

Based on the conclusions above, several suggestions can be made for this research, namely:

a. This research is only carried out in one sector, namely companies engaged in property, it is hoped that furthermore,

expanding to several sectors of companies listed on the stock exchange so that they can be used as references to generalize to all types of companies. Profitability measurement in this study is measured using ROE (return on equity), it is expected to use other proxies such as ROA (return on assets) and ROI (return on investment).

b. The results of this study are expected to be a reference for shareholders in making decisions in order to make companies engaged in the property sector a target for investors in investing in property so that in this sector the company can make this company a going concern company.

c. The results of this study indicate that investors can consider investing and can take into account the company's profitability, so choose a good company to provide business capital or buy shares of one or more property company shares.

\section{References}

Bich Thi Nguyen (2015), Association Between Corporate Social Responsibility Disclousures and Company value - Empirical Evidence From Vietnam : University of Economics Hochiminh City. Vietnam

Dharmawan, Akhmad, Ciptaningrum,Fitri dan Aryoko,Yusdistira. 2020. Analisis Hubungan Tingkat Pertumbuhan, Ukuran Perusahaan, Dan Profitabilitas Terhadap Nilai Perusahaan Dengan Struktur Modal Sebagai Variabel Moderasi Pada Perusahaan Manufaktur Industri Barang Konsumsi Yang Terdaftar Di Bei Tahun 2015-2018

Fernandes Moniaga. (2014), Struktur Modal, Profitabilitas, Struktur Biaya terhadap Nilai Perusahaan : Universitas Sam Ratulangi. Manado

Hartono, Jogiyanto. (2010). Teori Portofolio dan Analisis Investasi, Yogyakarta: BPFE Edisi Kedua

Horne, James C. Van dan John M. Wachowicz Jr. (2010).Fundament of Financial Management Prinsip-prinsip Manajemen Keuangan.Edisi 12 Buku 2. Jakarta: Salemba Empat.

Harmono. (2009). Manajemen Keuangan Berbasis Balanced Scorecard (Pendekatan Teori, Kasus, dan Riset Bisnis). Bumi Aksara, Jakarta.

Hery. (2018). Financial Ratio For Business (Analisis Keuangan Untuk Menilai Kondisi Finansial dan Kinerja Perusahaan). PT. Gramedia Widiasarana Indonesia. Jakarta

Hasibuan, Dzulkirom, dan Endang. (2016), Pengaruh Leverage, dan Profitabilitas Terhadap Nilai Perusahaan : Universitas Brawijaya. Malang

Irayanti dan Tumbel. (2014), Analisis Kinerja Keuangan Pengaruhnya Terhadap Nilai Perusahaan Pada Industri Makanan dan Minuman di BEI : Universitas Sam Ratulangi. Manado

Kasmir,2009. Pengantar manajemen keuangan. Fajar interprana offset. Jakarta

Khoirianto, R. (2016). Pengaruh Profitabilitas dan Kebijakan Dividen terhadap Nilai Perusahaan dengan Struktur Modal sebagai Variabel Intervening (Studi pada Perusahaan Manufaktur yang Listing Di Bursa Efek Indonesia Periode 2009-2012). Akuntabilitas Jurnal Ilmiah Ilmu-Ilmu Ekonomi, 9(1)

Kusumajaya, Dewa Kadek Oka. (2011). Pengaruh Struktur Modal dan Pertumbuhan Perusahaan terhadap Profitabilitas dan Nilai Perusahaan Pada Perusahaan Manufaktur di Bursa Efek Indonesia. Tesis Program Pascasarjana Universitas Udayana.

Murni, dkk. (2019), The Role of Financial Performance in Determining The Company value : Universitas Sam 
Ratulangi. Manado

Mulya dan Probowo (2018), The Impact of Sustainability Reports toward the Company value : European Research Studies Journal Volume XXI, Issue 4, 2018. Indonesia

Munthe, Inge Lengga Sari. (2018). The effect of Profitability to Firm's Value with Capital Structure as Moderating Variable at Manufacturing Company Industry Consumer Goods Sub Sector Food and Beverage 2014 - 2017. Jurnal Ilmiah Akuntansi dan Finansial Indonesia Volume 1, No.2, April 2018.

Nopiyanti dan Darmayanti. (2016). Pengaruh PER, Ukuran Perusahaan, dan Profitabilitas pada nilai perusahaan dengan struktur modal sebagai variable moderasi : E-Jurnal Manajemen Unud, Vol. 5, No.12, 2016: 78687898 ISSN : 2302-8912: Universitas Udayana. Bali

Puspitasari, Elen dan Bambang Sudiyanto. 2010. Tobin's Q dan Altman Z-score Sebagai Indikator Pengukur Kinerja Perusahaan. Jurnal Kajian Akuntansi. Vol. 2, No. 1, februari : 9-21.

Rudangga dan Sudiarta. (2016). Pengaruh Ukuran Perusahaan, Leverage, dan Profitabilitas Terhadap Nilai Perusahaan : E-Jurnal Manajemen Unud, Vol. 5, No.7, 2016: 4394 - 4422 ISSN : 2302-8912 : Universitas Udayana. Bali

Sulindawati, dkk. (2016). Manajemen Keuangan Sebagai Dasar Pengambilan keputusan Bsnis. Rajagrafindo Persada. Depok

Sujarweni. (2016). Manajemen Keuangan Teor, Aplikasi, dan Hasil Penelitian. Pustaka Baru Press. Yogyakarta Sudana, I Made. (2009). Manajemen Keuangan : Teori dan Praktek. Surabaya: Airlangga University Press

Solimun dkk. (2017). Metode Statistika Multivariat Permodelan Persamaan Struktural (SEM):UB Press. Malang

Sambora, Handayani, dan Rahayu. 2014, Pengaruh Leverage dan Profitabilitas terhadap Nilai perusahaan: Universitas Brawijaya. Malang

Selin Lumoly, dkk. (2018), Pengaruh Likuiditas, Ukuran Perusahaan, dan Profitabilitas Terhadap Nilai Perusahaan : Universitas Sam Ratulangi. Manado

Tandelilin, Eduardus. (2010). Analisis Investasi dan Manajemen Portofolio, Edisi: Pertama. Yogyakarta: BPFE. Wiagustini,Ni luh Putu. (2010). Dasar- Dasar Manajemen Keuangan. Denpasar: Udayana University Press.

Wijaya, Anggita Langgeng dan Erlita Listyana Pancawati. 2019. Pengaruh Pengungkapan Corporate Social Responsibility (CSR) dan Profitabilitas terhadap Nilai Perusahaan dengan Struktur Modal sebagai Variabel Pemoderasi. Jurnal Akuntansi Vol. 3 No. 2 Oktober 2019. 